\title{
АНАЛІЗ НОРМАТИВНО-ПРАВОВОЇ БАЗИ, ЩО РЕГЛАМЕНТУЄ РОБОТУ ПСИХІАТРИЧНОї СЛУЖБИ УКРАЇНИ
}

\author{
Д3 «Запорізька медична академія післядипломної освіти МОЗ України», м. Запоріжжя, Україна
}

\begin{abstract}
Мета роботи - провести аналіз нормативно-правової бази, що регламентує роботу психіатричної служби України з метою удосконалення надання психіатричної допомоги на первинному рівні ЛЗП/Сл.

Матеріали і методи. Матеріалами дослідження стали нормативно-правові акти з питань надання психіатричної допомоги в Україні. Для вивчення та аналізу нормативно-правової бази використано метод контент-аналізу.

Результати. Провівши детальний аналіз нормативно-правовї бази психіатричної допомоги України, а також додаткові дослідження щодо надання медичної допомоги хворим із розладами психіки та поведінки, враховуючи реформування у сорері охорони здоров'я та перехід до ПМСД, з метою удосконалення надання психіатричної допомоги на первинному рівні ЛЗП/СЛ, пропонуємо внести деякі зміни до Закону України № 1489-ІІІ від 22.02.2000р. «Про психіатричну допомогу».

Висновки. Доведено необхідність внесення змін до ст. 11, 12, 27 Закону України «Про психіатричну допомогу» в частині надання законодавчого права проведення психіатричних оглядів, надання психіатричної допомоги лзП/СЛ на первинному рівні.
\end{abstract}

КЛЮчОВІ СЛОВА: психіатрична служба України; законодавство;захист прав людини.

Психіатрія - це галузь медичної діяльності, яка завжди була найбільш актуальною з питань правового регулювання, а тим більше українська психіатрія. Україна належить до країн, які входили до СРСР, а отже, історія української психіатрії є прикладом того, як відсутність правого регулювання психіатричної медичної допомоги, ігнорування прав пацієнтів здатне негативно позначитися як на самій психіатрії, так і на тих, хто пов'язаний 3 наданням психіатричної допомоги.

Психіатрична допомога в Україні надається за принципами законності, гуманності, дотримання прав людини і громадянина, добровільності, доступності, але до сьогодні зберігає радянські принципи організації, тобто загальнодоступність, територіальність, всебічність, а також відґалуженність від загальної мережі охорони здоров'я, централізація процесу надання допомоги у великих психіатричних лікарнях, що нав'язують планування і розподіл ресурсів на користь стаціонарної ланки $[2,3,5,6]$.

Мета роботи - провести аналіз нормативноправової бази, що регламентують роботу психіатричної служби України 3 метою удосконалення надання психіатричної допомоги на первинному рівні ЛЗП/СЛ.

Матеріали і методи дослідження. Матеріалами дослідження стали нормативно-правові акти 3 питань надання психіатричної допомоги в Україні. Для вивчення та аналізу нормативно-правової бази використано метод контент-аналізу.

(с) 3.В. Лашкул, І.Г. Бібик, 2017
Результати дослідження та їх обговорення. На сьогодні роботу психіатричної служби України регламентують нормативно-правові акти, в тому числі Закон України № 1489-ІІІ від 22.02.2000р. «Про психіатричну допомогу», який $€$ одним 3 основних документів у роботі лікаря-психіатра. Враховуючи основні принципи організації служб психіатричної допомоги, сфрормульовані ВООЗ:

1) захист прав людини - кожна людина не повинна обмежуватися у своїх правах. Необхідно поважати незалежність будь-якого хворого та надавати гідні умови і методи лікування всім, без винятку, хворим;

2) доступність - психіатрична допомога повинна надаватися хворим у будь-який час та в будь-якій місцевості, навіть у найвіддаленіших куточках країни (сільській місцевості);

3) всебічність - психіатрична допомога повинна надаватися в усіх фрормах та видах, виходячи з потреб населення;

4) безперервність та узгодженість - психіатрична допомога повинна надаватися в будь-який час та бути злагодженою між лікарями усіх спеціальностей;

5) дієвість - психіатрична допомога повинна бути науково обґрунтованою;

6) рівноправність - психіатрична допомога повинна надаватися у повному обсязі усім особам, які її потребують, без винятку;

7) економічна ефрективність - при розвитку служб психіатричної допомоги та розподілі коштів необхідно брати до уваги економічну ефективність 
$[4,7]$, а також те, що основними пріоритетами у сорері психічного здоров'я $€$ розвиток комплексної системи профілактики, діагностики, лікування та реабілітації при психічних розладах, головними завданнями, на нашу думку, повинні бути:

- вдосконалення методів профрілактики психічних розладів, розробка та реалізація консультативної допомоги, навчальних програм для населення з питань охорони психічного здоров'я та профрілактики суїцидів;

- вдосконалення методів діагностики та лікування психічних розладів, впровадження бригадних форм роботи в умовах психіатричного стаціонару, денного стаціонару та психоневрологічного диспансеру;

- соціалізація хворих із тяжкими психічними розладами після інтенсивного стаціонарного лікування.

Дотримуючись принципів надання медичної допомоги при розладах психіки та поведінки, необхідно виконувати наступні умови:

1. Доступність - надання медичної допомоги пацієнтам, з розладами психіки та поведінки, необхідно здійснювати на первинному рівні. Тобто за бажанням пацієнта медичну допомогу у сорері охорони психічного здоров'я повинен надавати ЛЗП/СЛ.

2. Безперервність - безперервний доступ не тільки до медичної допомоги, а й допомога в соціальній, професійній адаптації, вирішення психологічних проблем для пацієнтів, які цього потребують.

3. Повний спектр послуг - не тільки надання медичної допомоги, ассертивна терапія, але й санаторно-курортне лікування, підтримка та втручання під час кризових ситуацій, вирішення соціальних проблем, пов'язаних із житлом, працевлаштування, надання ургентної допомоги спеціальними службами, які повинні працювати цілодобово.

4. Адаптованість - служби охорони здоров'я повинні надавати послуги відповідно до допотреб пацієнтів.

5. Ефрективність - розвиток послуг, що надаються хворим з розладами психіки та поведінки, повинні бути ефективними, тобто керуватися принципами доказової медицини.

6. Акцент на реабілітації, тобто після вдалого лікування медичними препаратами або на фоні цього, необхідно впроваджувати активну реабілітацію. Впровадження на фрармацевтичному ринку нових поколінь нейролептиків зі значно нижчими побічними еоректами покращує процес реабілітації.

7. Допомога близьких - участь сім'ї, опікунів, друзів у процесі реабілітації, соціальної та професійної адаптації пацієнтів.

8. Профрілактика - проведення роз'яснювальних та навчальних занять в усіх навчальних закладах країни, на великих підприємствах. За можливості усунення та запобігання фракторам ризику.

9. Справедливість - тобто усі верстви населення, незалежно від їх соціального становища, місця проживання, національності повинні отримувати однакову медичну допомогу, реабілітацію, соціальну та професійну допомогу.

Провівши детальний аналіз нормативно-правовї бази психіатричної допомоги України, а також додаткові дослідження щодо надання медичної допомоги хворим із розладами психіки та поведінки, враховуючи реформування у сорері охорони здоров'я та перехід до ПМСД, з метою удосконалення надання психіатричної допомоги на первинному рівні ЛЗП/СЛ пропонуємо внести деякі зміни до Закону України № 1489-ІІІ від 22.02.2000 р. «Про психіатричну допомогу».

Згідно зі статтею 11 Закону України № 1489-ІІІ від 22.02.2000 р. «Про психіатричну допомогу», де зазначено, що «психіатричний огляд проводиться ЛП на прохання або за усвідомленою згодою особи; щодо особи віком до 14 років (малолітньої особи) - на прохання або за згодою її батьків чи іншого законного представника; щодо особи, визнаної у встановленому законом порядку недієздатною, - на прохання або за згодою ії опікуна», а також статті 12 Закону України «Про психіатричну допомогу» «амбулаторна психіатрична допомога надається ЛП на прохання або за усвідомленою згодою особи; щодо особи віком до 14 років (малолітньої особи) - на прохання або за згодою їі батьків чи іншого законного представника; щодо особи, визнаної у встановленому законом порядку недієздатною, - на прохання або за згодою її опікуна» [1].

Тому керуючись вищезазначеними принципами в наданні медичної допомоги хворим з розладами психіки та поведінки, ми сформулювали пропозиції внесення змін до відповідних статей в Закон України «Про психіатричну допомогу», які викласти в наступній редакції: статтю 11 - «Психіатричний огляд проводиться ЛЗП/СЛ, ЛП на прохання або за усвідомленою згодою особи; щодо особи віком до 14 років (малолітньої особи) - на прохання або за згодою її батьків чи іншого законного представника; щодо особи, визнаної у встановленому законом порядку недієздатною, - на прохання або за згодою її опікуна».

Статтю 12 - «амбулаторна психіатрична допомога надається ЛЗП/СЛ, ЛП на прохання або за усвідомленою згодою особи; щодо особи віком до 14 років (малолітньої особи) - на прохання або за згодою її батьків чи іншого законного представника; щодо особи, визнаної у встановленому законом порядку недієздатною, - на прохання або за згодою її опікуна».

Відповідно до цих змін необхідно також внести зміни в статтю 27, абзаци 3-6 та викласти їх в наступній редакції:

«При наданні психіатричної допомоги лікарпсихіатр, комісія лікарів-психіатрів, лікар загальної практики/сімейний лікар незалежні у своїх 
рішеннях і керуються лише медичними показаннями, своїми професійними знаннями, медичною етикою та законом.

Лікар-психіатр, комісія лікарів-психіатрів, лікар загальної практики/сімейний лікар несуть відповідальність за прийняті ними рішення відповідно до закону.

Рішення, прийняте лікарем-психіатром, комісією лікарів-психіатрів або лікарем загальної практики/ сімейним лікарем при наданні психіатричної допомоги, викладається у письмовій фрормі та підписується лікарем-психіатром, комісією лікарів-психіатрів або лікарем загальної практики/сімейним лікарем.

Лікар-психіатр, комісія лікарів-психіатрів або лікар загальної практики/сімейний лікар мають право відмовити у наданні психіатричної допомоги у разі відсутності підстав для її надання. Відмова у наданні психіатричної допомоги із зазначенням ії причин фріксується у медичній документації за підписом особи чи її законного представника та лікаря-психіатра, комісії лікарів-психіатрів або лікаря загальної практики/сімейного лікаря.

Лікар-психіатр, лікарі загальної практики/ сімейні лікарі, інші працівники, які беруть участь у наданні психіатричної допомоги, мають право на конфіденційність відомостей про своє місце проживання, склад сім'ї, номер домашнього телефону тощо».

Тому запропоновано надати законодавче право проведення психіатричних оглядів, надання психіатричної допомоги, а також прийняття участі у роботі лікарської комісії ЛЗП/СЛ.
ЛЗП/СЛ, як і ЛП при первинному огляді пацієнта завжди повинен керуватися статтею 3 «Презумпція психічного здоров'я», а також статтею 6 «Конфіденційність відомостей про стан психічного здоров'я особи та надання психіатричної допомоги» Закону України «Про психіатричну допомогу». Тобто пацієнт, який звертається за медичною допомогою з приводу психічного здоров'я, повинен надавати усвідомлену згоду на психіатричний огляд та амбулаторне лікування.

\section{Висновки}

1. У результаті дослідження обґрунтовано та розроблено пропозиції щодо удосконалення системи надання амбулаторної психіатричної допомоги в умовах сімейної медицини, які полягають у підвищенні рівня доступності та якості медичної допомоги, соціальної адаптації особам з розладами психіки та поведінки.

2. Доведено необхідність внесення змін до ст. 11, 12, 27 Закону України «Про психіатричну допомогу» в частині надання законодавчого права проведення психіатричних оглядів, надання психіатричної допомоги ЛзП/СЛ на первинному рівні, що надасть можливість не тільки направлення пацієнтів, які звертаються з приводу психічного здоров'я до ЛП, а й встановлення діагнозу і проведення лікування (за умов достатньої кваліфрікації ЛЗП/СЛ, та вибору лікувального закладу і лікаря пацієнтом), а також прийняття їх участі у роботі лікарської комісії.

Перспективи подальших досліджень полягають у проведенні дослідження нормативно-правової бази, що регламентує роботу ЛЗП/СЛ в Україні.

\section{Список літератури}

1. «Про психіатричну допомогу» : Закон України //Відомості Верховної Ради України. - 2000, № 19. С.143) Із змінами, внесеними згідно із Законами N 1364-IV ( 1364-15 ) від 09.12.2003, ВBP, 2004, N 15, ст.221 N 1033-V (1033-16) від 17.05.2007, BBP, 2007, N 34, ст.445,N 4795-VI ( 4795-17) від 22.05.2012.

2. Краснов В. Н. Расстройства афффективного спектра / В. Н. Краснов.- М., 2011. - 431 с.

3. Краснов С. Ю. Научное обоснование организации амбулаторной помощи страдающим психическими расстройствами в современных социально-правовых условиях: дисс. ... канд. мед. наук. - СПб., 2005. - 140 с.

4. Организация служб охраны психического здоровья (Свод методических рекомендаций по вопросам политики и оказания услуг в области психического здоровья). Всемирная организация здравоохранения. - Копенгаген. - 2006. - 92 с.

5. Петров Д. С. Пути совершенствования амбулаторной помощи пациентам с психическими расстройствами (медико-социальное и клинико-организационное исследование) : дис. ... канд. мед. наук. - М., 2011. - 153 с.

6. Kirchner J. Using a multi-level approach to implement a primary care mental health (PCMH) program / JoAnn Kirchner, Carrie N. Edlund, Kathy Henderson [et al.] // Families, Systems, \& Health. - 2010. - № 28(2). - P. 161-174.

7. Promoting mental health: concepts, emerging evidence, practice : report of the World Health Organization, Department of Mental Health and Substance Abuse in collaboration with the Victorian Health Promotion Foundation and the University of Melbourne [Електроний ресурс] / editors: H. Herrman, Sh. Saxena, R. Moodie/ World Health Organization. - 2005. 288 р. Режим доступу: http://www.who.int/mental_health/evidence/MH_Promotion_Book.pdf.

\section{References}

1. Zakon Ukrainy «Pro psykhiatrychnu dopomohu»[The Law of Ukraine «On Psychiatric Aid»]. (n.d.). Vidomosti Verkhovnoi Rady Ukrainy - Information from the Verkhovna Rada of Ukraine, 2000, N 19, st.143) Iz zminamy, vnesenymy zhidno iz Zakonamy N 1364-IV ( 1364-15 ) vid 09.12.2003, VVR, 2004, N 15, st.221 N 1033-V (1033-16) vid 17.05.2007, VVR, 2007, N 34, st.445,N 4795-VI ( 4795-17) vid 22.05.2012 [As amended by the Laws of Ukraine].

2. Krasnov, V.N. (2011). Rasstroystva affektivnogo spektra [The disorders of the affective spectrum]. Moscow [in Russian]. 3. Krasnov, S.Yu. (2005). Nauchnoye obosnovaniye organizatsii ambulatornoy pomoshchi stradayushchim psikhicheskimi rasstroystvami v sovremennykh sotsialno-pravovykh usloviyakh [Scientific substantiation of the organization of outpatient care for people suffering from mental disorders in modern social and legal conditions]. Extended abstract of Candidate's thesis. St.Petersburg [in Russian]. 
4. World Health Organization. (2006). Organization of Mental Health Services (Code of Practice on Mental Health Policy and Service Delivery). Copenhagen

5. Petrov, D.S. (2011). Puti sovershenstvovaniya ambulatornoy pomoshchi patsiyentam s psikhicheskimi rasstroystvami (mediko-sotsialnoye i kliniko-organizatsionnoye issledovaniye) [Ways to improve outpatient care for patients with mental disorders (medico-social and clinico-organizational research)]. Extended abstract of candidate's thesis. Moscow [in Russian].

6. Kirchner, JoAnn, Edlund, Carrie N., \& Henderson Kathy (2010). Using a multi-level approach to implement a primary care mental health (PCMH) program. Families, Systems, \& Health. 28(2). 161-174.

7. Herrman, H., Saxena, Sh., \& Moodie R. (Eds). (2005). Promoting mental health: concepts, emerging evidence, practice: report of the World Health Organization, Department of Mental Health and Substance Abuse in collaboration with the Victorian Health Promotion Foundation and the University of Melbourne. World Health Organization. 288 p. Retrieved from :http://www.who.int/mental_health/evidence/MH_Promotion_Book.pdf.

\section{АНАЛИЗ НОРМАТИВНО-ПРАВОВОЙ БАЗЫ, РЕГЛАМЕНТИРУЮЩЕЙ РАБОТУ ПСИХИАТРИЧЕСКОЙ СЛУЖБЫ УКРАИНЫ}

3.В. Лашкул, И.Г. Бибык

ГУ «Запорожская медицинская академия последипломного образования МЗ Украины», г. Запорожье, Украина

Цель работы - провести анализ нормативно-правовой базы, регламентирующей работу психиатрической службы Украины с целью усовершенствования оказания психиатрической помощи на первичном уровне ВОП / СЛ.

Материалы и методы. Материалами исследования стали нормативно-правовые акты по вопросам оказания психиатрической помощи в Украине. Для изучения и анализа нормативно-правовой базы использован метод контент-анализа.

Результаты. Проведя детальный анализ нормативно-правовой базы психиатрической помощи Украине, а также дополнительные исследования по оказанию медицинской помощи больным с расстройствами психики и поведения, учитывая реформирование в сфере здравоохранения и переход к ПМСП, с целью совершенствования оказания психиатрической помощи на первичном уровне ВОП / СВ, предлагаем внести некоторые изменения в Закон Украины № 1489-ІІІ от 22.02.2000 р. «О психиатрической помощи».

Выводы. Доказананеобходимость внесения изменений вст. 11, 12, 27 ЗаконаУкраины «Опсихиатрической помощи» в части предоставления законодательного права проведения психиатрических осмотров, оказания психиатрической помощи ВОП / СВ на первичном уровне.

КЛЮЧЕВЫЕ СЛОВА: психиатрическая служба Украины; законодательство; защита прав человека.

\section{ANALYSIS OF THE LEGAL FRAMEWORK GOVERNING THE WORK OF MENTAL HEALTH SERVICES OF UKRAINE}

Z. V. Lashkul, I. H. Bibyk

Zaporizhzhia Medical Academy of Postgraduate Education, Zaporizhzhia, Ukraine.

The aim of the work - to analyze the legal framework governing the work of psychiatric Service of Ukraine to improve psychiatric care at the primary level GP / FD.

Materials and Methods. The study materials were regulations on the provision of mental health care in Ukraine. To study and analysis of the legal framework we used method for content analysis.

Results. After a detailed analysis of the legal framework psychiatric help Ukraine, and more research to provide medical care to patients with mental and behavioral disorders, including reforms in health care and the transition to primary health care, to improve the provision of mental health care at the primary level GP / FD offer to make some changes to the Law of Ukraine № 1489-III of 22.02.2000. «On psychiatric care».

Conclusions. The necessity of amending the century. 11, 12, 27 of the Law of Ukraine «On psychiatric care» in terms of providing legal rights of psychiatric examinations, psychiatric care GP / SL at the primary level.

KEY WORDS: psychiatric service of Ukraine; legislation; protection of human rights.

Відомості про авторів:

Лашкул Зінаїда Василівна - д.мед.н., доцент, завідувач кафедри соціальної медицини, організації і управління охороною здоров'я та медико-соціальної експертизи Д3 «Запорізька медична академія післядипломної освіти МОЗ України»; тел. (061) 233-32-47

Бібик Інесса Геннадіївна - к.мед.н., старший викладач кафедри соціальної медицини, організації і управління охороною здоров'я та медико-соціальної експертизи ДЗ «Запорізька медична академія післядипломної освіти МОЗ України»; тел. (+38099) 2-200-200 